\title{
The Effect of Water and Sewage Treatment on Reducing Residues of Selected Organochlorine Pesticides in Szczecin (Poland)
}

\author{
Jacek Cybulski (1) - Agata Witczak (D) \\ Kamila Pokorska-Niewiada
}

Received: 25 June 2020 / Accepted: 4 July 2021 / Published online: 17 July 2021

(C) Springer Nature Switzerland AG 2021

\begin{abstract}
Water is principally intended for direct consumption and for the production of food and beverages. It is also a valuable raw material in the industry. Despite the use of multi-stage treatment processes, the quality of drinking water may still be a concern in some countries due to the presence of toxic pollutants, often challenging to remove through the conventional treatment process. The presence of even trace amounts of organochlorine pesticides in drinking water is dangerous due to their ability to accumulate in the human body and their effects, especially their capacity for endocrine disruption. The present study aimed to assess the effect of water and sewage treatment on the efficiency of reducing residues of selected organochlorine pesticides in drinking water and treated sewage. It was found that the water treatment process reduced concentrations of these compounds by an average of $80 \%(46-100 \%)$ and that the levels of organochlorine pesticides in the drinking water were no higher than $0.55 \%$ the maximum residue limit (MRL). The sewage treatment process led to
\end{abstract}

J. Cybulski $(\bowtie) \cdot$ A. Witczak $\cdot$ K. Pokorska-Niewiada Department, of Toxicology, Dairy Technology and Food Storage, Faculty of Food Sciences and Fisheries, West Pomeranian University of Technology, Szczecin, Poland e-mail: jacek.cybulski@zut.edu.pl

A. Witczak

e-mail: agata.witczak@zut.edu.pl

K. Pokorska-Niewiada

e-mail: kamila.pokorska@zut.edu.pl a reduction in organochlorine pesticide concentration of $37-100 \%$, averaging $85 \%$, and the sums of organochlorine pesticide residues in treated sewage ranged between 0.02 and $14.97 \mathrm{ng} / \mathrm{L}$ in annual terms.

Keywords Organochlorine pesticides · Drinking water - Treatment effectiveness

\section{Introduction}

Water is an essential element used in the production of food and beverages and for direct consumption. It is also a vital raw resource in the industry (Aryal et al., 2012, Cosgrove \& Loucks, 2015). Water can also be used to maintain hygiene in industrial and residential properties. In EU countries, Council Directive 98/83/EC (1998) is the prevailing Directive governing water-quality parameters for drinking water consumed by humans. Pursuant to the Directive, drinking water must be free of microbes, parasites, and harmful chemicals that may be hazardous to human health. Every 3 years, Member States provide a report on drinking water quality to the EU Commission. In turn, every 5 years, these reports are used to verify microbiological, chemical, and indicatory parameters, as well as mechanisms for monitoring (Council Directive 98/83/EC).

A water treatment process usually consists of the following stages: filtration, aeration, coagulation, sedimentation, sedimentation through a sand and carbon 
filters, and disinfection. Despite the use of multi-stage treatment processes, the quality of drinking water may still be a concern in some countries due to the presence of toxic pollutants, often difficult to remove through the conventional treatment process. Some compounds, including those classified as persistent organic pollutants (POPs), e.g., organochlorine pesticides, polychlorinated biphenyls (PCBs), dioxins, and hexachlorobenzene (HCB), as well as some agricultural chemicals, are not fully removed through treatment and persist in the water (Li et al., 2006, Farhaoui \& Derraz, 2016, Mekonen et al., 2016). Organochlorine pesticides, such as dieldrin, chlordane, DDT (dichlorodiphenyltrichloroethane), DDE (dichlorodiphenyldichloroethylene), $\quad \beta$-hexachlorocyclohexane $(\beta \mathrm{HCH})$, carbon tetrachloride, heptachlor, and $\gamma$-hexachlorocyclohexane (lindane, gamma-hexachlorocyclohexane, $\gamma \mathrm{HCH}$ ), are resistant to conversion through weather and biochemical conditions, do not readily break down in living organisms, and, when present in water, may lead to the formation of persistent metabolites. These compounds show great variation in their structure and physical-chemical properties. In addition to their persistence and resistance to chemical and biological agents, they are also highly fat-soluble, and thus bioaccumulate in living organisms (Perelló et al., 2012). While they exhibit water solubility, these compounds are nonetheless found in water in trace amounts, for example, in adsorbed form on particulate matter (Lana et al., 2008, Pawełczyk, 2013). They may also accumulate in bottom sediments and recirculate into surface waters (Olutona et al., 2014).

The presence of even trace amounts of organochlorine pesticides in drinking water is dangerous due to their ability to accumulate in the human body and their effects, especially their capacity for endocrine disruption, especially given the quantities of water consumed $-2 \mathrm{~L}$ a day on average (Tsindos, 2012). The human body is very slow to excrete such pollutants. For example, the metabolic half-life of DDT in adipose tissue is between 5 and 7 years. Adverse effects include neurotoxic disorders, endocrine disruption, changes in enzyme activity, and even carcinogenesis (Piccoli et al., 2016, Polanco-Rodriguez et al., 2017). Endocrine disruption may involve various mechanisms, such as the disruption of hormone synthesis and secretion (Feng et al., 2016, Wee \& Aris, 2017).
The Miedwie Lake catchment area is made up of agricultural areas where OCP was used. In the years 1983-1988, the Institute of Plant Protection in Poznań conducted extensive research on pesticide pollution in the waters of Lake Miedwie. Of the 58 compounds, the most frequently detected pesticides were $\mathrm{\gamma HCH}$, $\alpha-\mathrm{HCH}, \beta-\mathrm{HCH}$, cypermethrin, and permethrin. OCP has not been used for several decades in the countries of the European Union and North America; however, atmospheric transport (from Asia and Africa) has still remained the main factor of water and atmosphere pollution. Another threat to the aquatic environment is the use in agriculture of the permitted insecticide Dicofol, which is produced from DDT in India and China (Koniuch \& Małozięć, 2007). The present study was aimed to assess the effect of water and sewage treatment on reducing residues of selected organochlorine pesticides in drinking water and treated sewage, reintroduced into the river Odra, within the city limits of Szczecin.

\section{Materials and Methods}

The material used for the study consisted of raw water, drinking water, raw sewage, and treated sewage. The study started in March 2018 and ran until March 2019. The sampling was performed four times a month. Each time, 3 samples of $5 \mathrm{~L}$ raw water, drinking water, raw sewage, and treated sewage were taken to be tested for pesticide levels (144 of samples yearly, any type of water, and sewage). The samples were secured by adding a solvent immediately after the sampling $(50 \mathrm{~mL}$ of hexane, Merck, purity $\geq 99.8 \%$ ).

\subsection{Raw and Drinking Water}

The raw water was sampled from Lake Miedwie, a source of drinking water and the largest freshwater reservoir in the Zachodniopomorskie (Western Pomerania) Voivodeship in Poland. The lake, $35 \mathrm{~km}^{2}$ in area, is the 5th largest lake in Poland and the 2nd largest in the voivodeship. The water is abstracted at two intake points. The intakes are 16-18 m deep (6 $\mathrm{m}$ above the lake bottom), located within the deepprofundal zone, and secured with grating with a $40 \mathrm{~mm}$ mesh. The raw water is treated in the Żelewo Water Production Plant (Zakład Produkcji Wody w 
Żelewie), situated within approximately $2.5 \mathrm{~km}$ from Lake Miedwie.

The treatment starts with the water being pumped from the lake intake point to the Żelewo Production Plant via a pipeline, equipped with a rotary $2 \mathrm{~mm}$ mesh capable of retaining particles larger than $3 \mathrm{~mm}$.

The water treatment process includes ozone oxidation, coagulation with PAX 1905 coagulant, flocculation with the use of polyelectrolytes, and then sedimentation and filtration on a sand bed and then an activated carbon bed.

The final water disinfection is conducted with chlorine gas and chlorine dioxide. The treated drinking water is transported to the city of Szczecin $(400,000$ population) through two 30-km-long mains, which supply water to $85 \%$ of the city's inhabitants (Fig. 1).

\subsection{Raw and Treated Sewage}

The "Pomorzany" modern water treatment plant in Szczecin has been in operation for 10 years. The plant treats water drawn from the left-bank part of Szczecin (North, West, and Downtown districts), representing approximately $50 \%$ of the city area. The plant catchment encompasses the old part of the city (downtown), which mostly has a combined sewage system, and the western and northern suburbs, which are mainly served by a sanitary system. Sewage is transported into the treatment plant using four delivery systems, from five pumping stations - Grabów, Dolny Brzeg, Górny Brzeg, Białowieska, and Szczawiowa - as well as from a waste storage point for transferred sewage, located at the edge of the plant premises. The sewage flows on through the treatment plant to the outlet leading to the Odra River, transported via gravity. The catchment area is mainly filled with domestic sewage, with a smaller share of industrial sewage. The combined nature of the sewage system within the catchment means that the daily volume of sewage flowing to the plant increases threefold during rainfall and snowmelt compared with the dry season. The raw sewage was sampled at the grating station, whereas the treated sewage at the outlet. The treatment process in the "Pomorzany" Sewage Treatment Plant involves both mechanical and biological treatment (Fig. 2).

The sewage is pumped into the grating station (mesh sizes $40 \mathrm{~mm}$ and $6 \mathrm{~mm}$ ). After the largest debris is screened out by the grating, the sewage is transported to four air sand separators. From there, the wastewater travels in 4 pre-settling tanks equipped with scraper chains; the dimensions of these tanks are $48.5 \mathrm{~m}$ long $\times 8 \mathrm{~m}$ wide $\times 3 \mathrm{~m}$ high. Mechanically treated sewage is transferred to the separation chamber, where it is then transported onto three separate biological treatment lines. After the biological treatment, the effluent is discharged into the Odra via the outlet. Some of the treated sewage is collected from the outlet and used in the operation of the plant. Extraction was carried out using hexane (Merck, purity $\geq 98.0 \%$ ) and acetone (Merck, purity $\geq 99.8 \%$ ), mixed in ratio by volume (V/V 3:1), in separatory funnels at the sampling date.

The extract was desiccated with anhydrous sodium sulfate $\left(\mathrm{Na}_{2} \mathrm{SO}_{4}\right.$, Merck, density $2.70 \mathrm{~g} /$ $\mathrm{cm}^{3}, 20^{\circ} \mathrm{C}$ ) and concentrated to $2 \mathrm{~mL}$ in a vacuum rotary evaporator (BUCHI Rotavapor R-300) in a $50{ }^{\circ} \mathrm{C}$ water bath. It was then washed with fuming sulfuric acid $\left(6 \mathrm{~mL} 7 \% \mathrm{SO}_{3}\right.$ in concentrated $\mathrm{H}_{2} \mathrm{SO}_{4}$, Merck, density $1.99 \mathrm{~g} / \mathrm{cm}^{3}, 20{ }^{\circ} \mathrm{C}$ ). The sewage samples were further purified on a sorbent bed (silica gel $/ \mathrm{Na}_{2} \mathrm{SO}_{4}$ ). After separation, the upper
Fig. 1 Diagram of the water treatment process at the Miedwie Water Production Plant

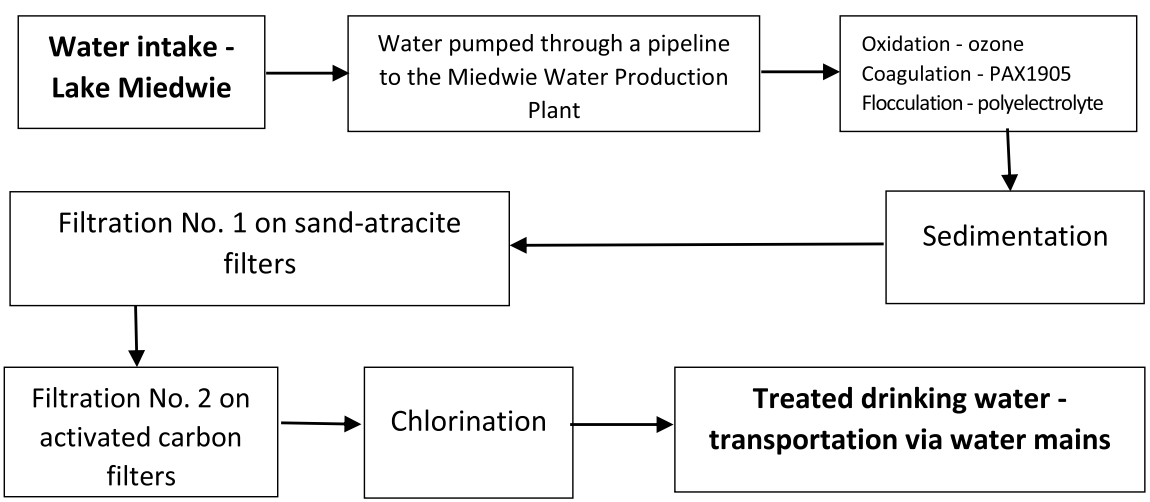


Fig. 2 Diagram of mechanical and biological treatment at the Pomorzany Sewage Treatment Plant in Szczecin. PIX, iron coagulant; PAX, aluminum coagulant

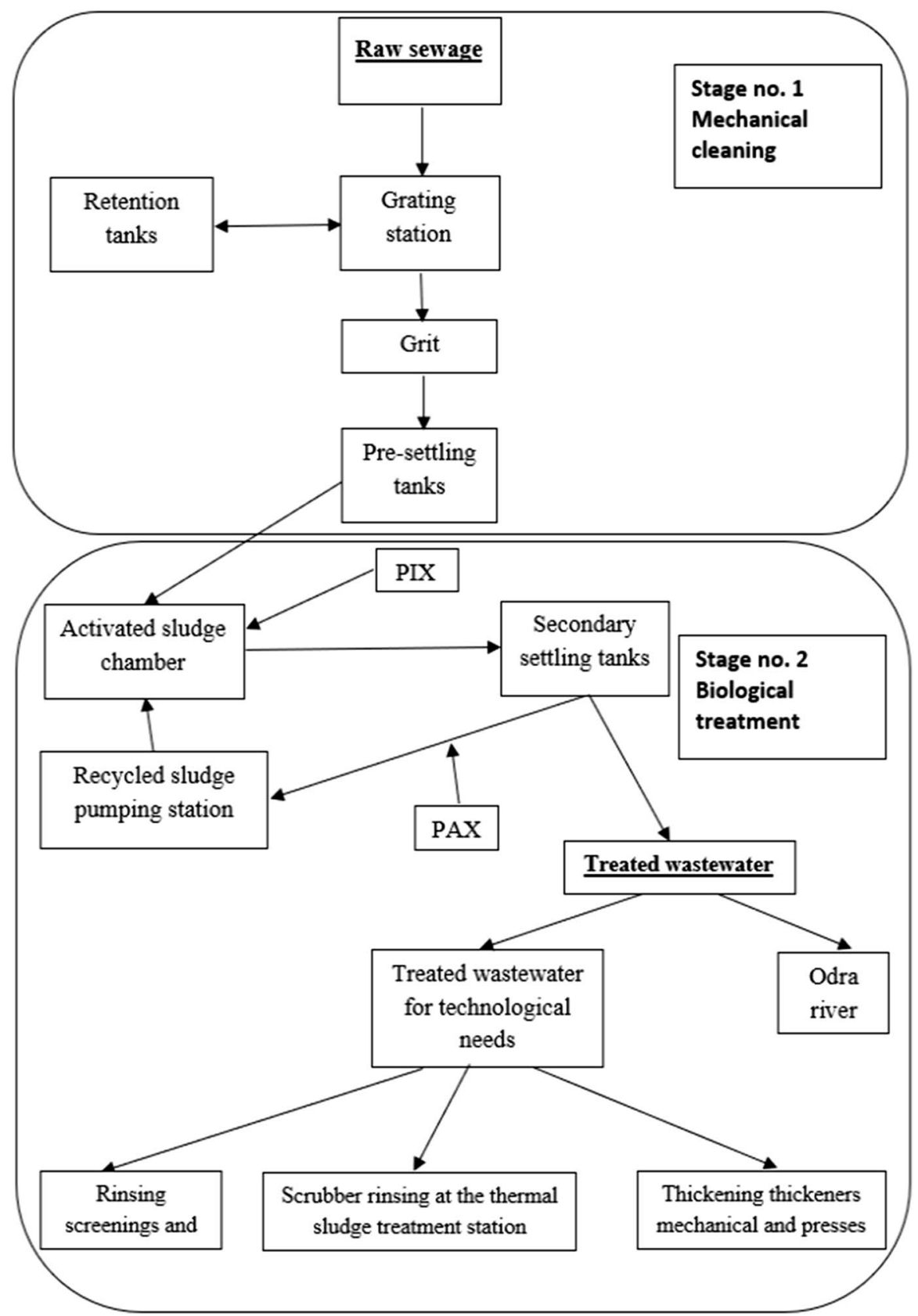

layer was transferred quantitatively (using hexane) into a $10-\mathrm{mL}$ test tube, after which the sample further washed with deionized water and desiccated with anhydrous sodium sulfate $(1.5 \mathrm{~g})$ in an 8 -mL LiChrolut ${ }^{\circledR}$ glass column. The samples were finally concentrated to $0.5 \mathrm{~mL}$ in a stream of nitrogen (Messer, purity 99.999\%). After the treatment, they were qualitatively and quantitatively analyzed using gas chromatography-mass spectrometry
(GC-MS). Method's accuracy was verified with an internal standard, consisting of Surrogat Spike Mix, Supelco pesticides (Mix-Supelco USA 4-9151): $\alpha \mathrm{HCH} \quad($ alpha-hexachlorocyclohexane), $\beta \mathrm{HCH}$, $\gamma \mathrm{HCH}, \delta \mathrm{HCH}$ (delta-hexachlorocyclohexane), heptachlor, aldrin, heptachlor epoxide isomer $\mathrm{B}$, dieldrin, pp'DDE, pp'DDT, pp'DDD (dichlorodiphenyldichloroethane), and endrin. The recovery of the analytes of interest ranged between 73 and $99 \%$. 
The limit of detection (LOD) for each compound was determined according to Commission Directive 2002/63/EC and ranged from 0.03 to $0.04 \mathrm{ng} / \mathrm{L}$. A blank method was included for every ten samples.

The limits of quantitation (LOQ) were estimated as (Eq. 1)

$\mathrm{LOQ}=10 \cdot \mathrm{S}$

where $\mathrm{S}$ is the standard deviation of ten independent measurements of the blank sample.

The chromatographic operating conditions for the analysis were column oven program: $90^{\circ} \mathrm{C}(0.5 \mathrm{~min}) \rightarrow$ increase $7 \quad{ }^{\circ} \mathrm{C} / \mathrm{min} \rightarrow 220 \quad{ }^{\circ} \mathrm{C} \quad(12 \quad \mathrm{~min}) \rightarrow$ increase $\quad 6 \quad{ }^{\circ} \mathrm{C} /$ min $\rightarrow 285{ }^{\circ} \mathrm{C}(7 \mathrm{~min}) \rightarrow$ Post Run $295^{\circ} \mathrm{C}(6 \mathrm{~min})$; single sample run time: $54.9 \mathrm{~min}$; carrier gas: helium; column flow rate: $0.8 \mathrm{~cm}^{3} \cdot \mathrm{min}^{-1}$; pressure: $7.4 \mathrm{psi}(0.05 \mathrm{MPa})$; detector MSD (HP 5973); column: HP-5MS (60.0 m; ID $250 \mu \mathrm{m}$; film thickness $0.25 \mu \mathrm{m}$ ). The chromatographic analysis was carried out in triplicate.

\subsection{Statistical analysis}

Statistical analysis was performed using Statistica 13.3 software. A correlation analysis $(p<0.05)$ was conducted, examining for association between sampling time and the levels of analytes of interest in raw water, drinking water, raw sewage, and treated sewage. The results are shown as medians, arithmetic means with uncertainty expressed at standard deviation, and minimum/maximum concentration levels. In turn, the one-way ANOVA test was used to examine the significant differences (Tukey's test) $(p<0.05)$.

The following parameters were used to assess the health risk associated with organochlorine pesticide exposure in humans:

(a) LADD (lifetime average daily dose), $\mathrm{mg} / \mathrm{kg} /$ day (Eq. 2):

$$
\mathrm{LADD}=\frac{c \cdot \mathrm{ADC}}{\mathrm{BW}}
$$

where $c$ is the average pesticide concentration in water, $\mathrm{ADC}$ is the average daily consumption of water, and BW is the mean body weight in adults (in $\mathrm{kg})$. (b) HQ (hazard quotient) (Eq. 3):

$\mathrm{HQ}=\frac{\mathrm{LADD}}{\mathrm{RfD}}$

where RfD is the reference dose $\left(\mathrm{mg} \cdot \mathrm{kg}^{-1} \cdot \mathrm{d}^{-1}\right)$.

HQ greater than or equal to 1.0 indicates the possibility of toxic effects occurring within the affected population.

\section{Results}

\subsection{Raw Water}

$\mathrm{HCH}$ compounds (>LOD) were found to be present in an average of $79 \%$ of the raw water samples $(\alpha \mathrm{HCH}, 75 \% ; \beta \mathrm{HCH}, 100 \%$; $\gamma \mathrm{HCH}, 67 \%$; $\mathrm{\delta HCH}, 75 \%)$. The lowest average content of the sum of HCHs in raw water was determined in May (0.08 ng/L), with the highest level in March 2019 $(14.8 \mathrm{ng} / \mathrm{L})$, with the average level for the study period being $8.6 \mathrm{ng} / \mathrm{L}$. $\beta \mathrm{HCH}$ was the predominant $\mathrm{HCH}$ isomer, with $\alpha \mathrm{HCH}$ being the lowest fraction. The pesticide $\beta \mathrm{HCH}$ was the only compound detected in raw water year-round.

DDT metabolites ( $>$ LOD) were found to be present in an average of $65 \%$ of the raw water samples (pp'DDE, 71\%; pp'DDD, 75\%; pp'DDT, 50\%). The lowest average content of the sum of DDT and their metabolites was found in raw water $(3.41 \mathrm{ng} / \mathrm{L})$ in July, with the average level for the study period being $0.71 \mathrm{ng} / \mathrm{L}$. Of these, the metabolite pp'DDD was the major compound. The average fraction of $\mathrm{pp}^{\prime} \mathrm{DDT}$ in the sum of DDT was 0.47 , indicating that no new quantities of the compound were introduced. Endosulfan species (>LOD) were found to be present in an average of $25 \%$ of the raw water samples (endosulfan I, 13\%; endosulfan II, 58\%; endosulfan sulfate, $4 \%$ ). The highest total content of endosulfan pesticides (endosulfan I, endosulfan II, endosulfan sulfate) was found in raw water $(1.90 \mathrm{ng} / \mathrm{L})$ in March 2018, with the average level being $0.72 \mathrm{ng} / \mathrm{L}$, and endosulfan II showing the highest levels. The results of the one-way ANOVA significance test (Tukey's test) $(p<0.05)$ showed that the content of the sums of organochlorine pesticides in raw water was significantly higher $(p<0.05)$ from July 2018 to March 2019 relative to the other periods. 


\subsection{Drinking Water}

$\mathrm{HCH}$ compounds (>LOD) were found to be present in most of the drinking water samples at, respectively, $\alpha \mathrm{HCH}, 75 \% ; \beta \mathrm{HCH}, 100 \%$; $\mathrm{\gamma HCH}, 58 \%$; $\mathrm{SHCH}, 67 \%$. The highest average content of the sum of HCHs in drinking water was detected in September at $4.72 \mathrm{ng} / \mathrm{L}$, with the mean annual level being $1.41 \mathrm{ng} / \mathrm{L}$. Of these, the $\beta \mathrm{HCH}$ isomer was the predominant compound, while the lowest levels were observed for the $\alpha \mathrm{HCH}$ isomer.

DDT metabolites (>LOD) were found to be present in an average of $72 \%$ of the drinking water samples (pp'DDE, 73\%; pp'DDD, 75\%; pp'DDT, 69\%). The lowest average content of the sum of DDT and their metabolites was found in drinking water $(0.32 \mathrm{ng} / \mathrm{L})$ in April, with the average residue level for the study period being $0.11 \mathrm{ng} / \mathrm{L}$. Of these, the metabolite $\mathrm{pp}^{\prime} \mathrm{DDD}$ was the major compound. The average fraction of $\mathrm{pp}^{\prime} \mathrm{DDT}$ in the sum of DDT was 0.36 , indicating that no new quantities of the compound were introduced.

Endosulfan species (>LOD) were found to be present in an average of $21.5 \%$ of the drinking water samples (endosulfan I, 2\%; endosulfan II, $63 \%$; endosulfan sulfate, $0 \%$ ). The highest content of the sum of endosulfan pesticides (endosulfan I, endosulfan II, endosulfan sulfate) was found in drinking water $(0.71 \mathrm{ng} / \mathrm{L})$ in April, with the average residue concentration for the study period being $0.15 \mathrm{ng} / \mathrm{L}$. Of these, endosulfan II was the predominant compound.
Pursuant to the Dz. U. (Polish Journal of Laws), item 2294, 2017, the MRL of aldrin, dieldrin, heptachlor, and heptachlor epoxide in drinking water are all $30 \mathrm{ng} / \mathrm{L}$. No exceedances nor the presence of heptachlor epoxide was detected during the study period. The annual average levels for aldrin, dieldrin, and heptachlor in drinking water corresponded to $1.17 \%, 1.69 \%$, and $0.33 \%$ MRL, respectively. The sum of organochlorine pesticides is the combined content of the following pesticides: $\alpha \mathrm{HCH}, \mathrm{HCB}$, $\beta \mathrm{HCH}, \gamma \mathrm{HCH}, \delta \mathrm{HCH}$, heptachlor, aldrin, heptachlor epoxide isomer $\mathrm{B}$, endosulfan I, pp'DDE, dieldrin, endrin, endosulfan II, pp'DDD, endrin aldehyde, endosulfan sulfate, pp'DDT, endrin ketone, and methoxychlor (Fig. 3) (Table 1). The average content of the pesticide residues detected in drinking water during the study period was $2.73 \mathrm{ng} / \mathrm{L}$ or $0.55 \% \mathrm{MRL}$ $(\mathrm{MRL}=500 \mathrm{ng} / \mathrm{L})$. The levels of individual compounds were not found to exceed limits within the study period, with the highest determined concentration $(12.21 \mathrm{ng} / \mathrm{L})$ corresponding to a maximum of 2.44\% MRL for the sum of pesticides (Dz. U., item 2294, 2017).

The sums of organochlorine pesticides found in drinking water were found at significantly higher $(p<0.05)$ levels from June to December 2018, relative to the other periods. Additionally, when the levels of analytes of interest were compared in raw water, drinking water, raw sewage, and treated sewage via a Tukey's test $(p<0.05)$, the results showed that pesticide residues in drinking water significantly
Fig. 3 Sum of organochlorine pesticides in annual terms in raw and drinking water, a statistically significant value $(p<0.05)$, b statistically insignificant value $(p<0.05)$

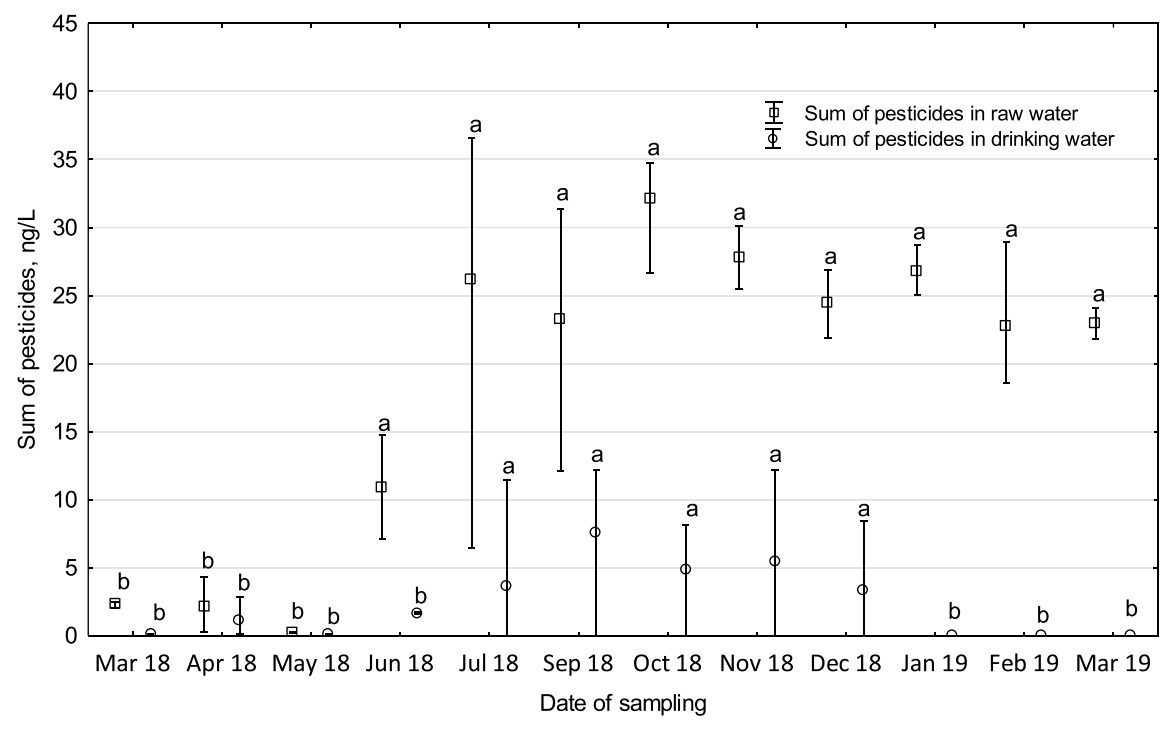


Table 1 Summary statistics of OCP concentrations (ng/L)

\begin{tabular}{|c|c|c|c|c|c|}
\hline Pesticide & & Raw water, $n=144$ & Drinking water, $n=144$ & Raw sewage, $n=144$ & Treated sewage, $n=144$ \\
\hline \multirow[t]{4}{*}{$\alpha \mathrm{HCH}$} & $\overline{\mathrm{x}} \pm \mathrm{SD}$ & $1.05 \pm 1.08$ & $0.21 \pm 0.32$ & $1.22 \pm 1.46$ & $0.32 \pm 0.48$ \\
\hline & $\mathrm{Me}$ & 0.93 & 0.00 & 0.19 & 0.00 \\
\hline & $\left(\mathrm{x}_{\min }-\mathrm{x}_{\max }\right)$ & $(0.23-3.99)$ & $(0.05-1.13)$ & $(0.10-4.40)$ & $(0.03-2.04)$ \\
\hline & $>\mathrm{LOD} \%$ & $75 \%$ & $75 \%$ & $83 \%$ & $79 \%$ \\
\hline \multirow[t]{4}{*}{$\mathrm{HCB}$} & $\overline{\mathrm{x}} \pm \mathrm{SD}$ & $0.07 \pm 0.08$ & $0.03 \pm 0.05$ & $0.17 \pm 0.35$ & $0.04 \pm 0.07$ \\
\hline & $\mathrm{Me}$ & 0.07 & 0.00 & 0.00 & 0.00 \\
\hline & $\left(\mathrm{x}_{\min }-\mathrm{x}_{\max }\right)$ & $(0.35-0.6)$ & $(0.03-0.24)$ & $(0.16-1.82)$ & $(0.06-0.21)$ \\
\hline & $>\mathrm{LOD} \%$ & $58 \%$ & $58 \%$ & $58 \%$ & $58 \%$ \\
\hline \multirow[t]{4}{*}{ ßHCH } & $\overline{\mathrm{x}} \pm \mathrm{SD}$ & $2.66 \pm 1.93$ & $0.48 \pm 0.98$ & $1.74 \pm 2.05$ & $0.46 \pm 0.61$ \\
\hline & $\mathrm{Me}$ & 3.41 & 0.07 & 0.29 & 0.10 \\
\hline & $\left(\mathrm{x}_{\min }-\mathrm{x}_{\max }\right)$ & $(0.03-4.92)$ & $(0.03-4.60)$ & $(0.29-6.31)$ & $(0.05-1.87)$ \\
\hline & $>\mathrm{LOD} \%$ & $100 \%$ & $100 \%$ & $92 \%$ & $96 \%$ \\
\hline \multirow[t]{4}{*}{ ұHCH } & $\overline{\mathrm{x}} \pm \mathrm{SD}$ & $1.96 \pm 2.27$ & $0.38 \pm 0.75$ & $1.96 \pm 2.55$ & $0.71 \pm 1.22$ \\
\hline & $\mathrm{Me}$ & 0.69 & 0.00 & 0.53 & 0.00 \\
\hline & $\left(\mathrm{x}_{\min }-\mathrm{x}_{\max }\right)$ & $(0.25-6.49)$ & $(0.20-3.47)$ & $(0.45-6.67)$ & $(0.28-4.55)$ \\
\hline & $>\mathrm{LOD} \%$ & $67 \%$ & $58 \%$ & $79 \%$ & $71 \%$ \\
\hline \multirow[t]{4}{*}{$\delta \mathrm{HCH}$} & $\overline{\mathrm{x}} \pm \mathrm{SD}$ & $2.92 \pm 2.94$ & $0.35 \pm 0.68$ & $2.27 \pm 3.29$ & $0.46 \pm 0.76$ \\
\hline & $\mathrm{Me}$ & 2.58 & 0.00 & 0.17 & 0.00 \\
\hline & $\left(\mathrm{x}_{\min }-\mathrm{x}_{\max }\right)$ & $(0.05-9.36)$ & $(0.09-2.77)$ & $(0.32-9.09)$ & $(0.13-3.14)$ \\
\hline & $>$ LOD $\%$ & $75 \%$ & $67 \%$ & $83 \%$ & $71 \%$ \\
\hline \multirow[t]{4}{*}{ Heptachlor } & $\overline{\mathrm{x}} \pm \mathrm{SD}$ & $0.44 \pm 0.53$ & $0.10 \pm 0.18$ & $0.60 \pm 1.09$ & $0.24 \pm 0.69$ \\
\hline & $\mathrm{Me}$ & 0.34 & 0.00 & 0.13 & 0.00 \\
\hline & $\left(\mathrm{x}_{\min }-\mathrm{x}_{\max }\right)$ & $(0.14-2.64)$ & $(0.10-0.99)$ & $(0.04-3.88)$ & $(0.04-3.81)$ \\
\hline & > LOD $\%$ & $75 \%$ & $75 \%$ & $79 \%$ & $75 \%$ \\
\hline \multirow[t]{4}{*}{ Aldrin } & $\overline{\mathrm{x}} \pm \mathrm{SD}$ & $4.44 \pm 4.01$ & $0.35 \pm 0.72$ & $1.70 \pm 2.54$ & $0.35 \pm 0.82$ \\
\hline & $\mathrm{Me}$ & 4.60 & 0.00 & 0.13 & 0.01 \\
\hline & $\left(\mathrm{x}_{\min }-\mathrm{x}_{\max }\right)$ & $(0.03-13.52)$ & $(0.02-3.39)$ & $(0.25-9.72)$ & $(0.04-4.90)$ \\
\hline & $>\mathrm{LOD} \%$ & $88 \%$ & $79 \%$ & $75 \%$ & $75 \%$ \\
\hline \multirow{4}{*}{$\begin{array}{l}\text { Heptachlor epoxide } \\
\text { isomer B }\end{array}$} & $\bar{x} \pm S D$ & $0.01 \pm 0.03$ & $0.00 \pm 0.00$ & $0.00 \pm 0.00$ & $0.00 \pm 0.01$ \\
\hline & $\mathrm{Me}$ & 0.00 & 0.00 & 0.00 & 0.00 \\
\hline & $\left(\mathrm{x}_{\min }-\mathrm{x}_{\max }\right)$ & $(0.12-0.13)$ & $(0.00-0.00)$ & $(0.00-0.00)$ & $(0.04-0.05)$ \\
\hline & $>\mathrm{LOD} \%$ & $4 \%$ & $0 \%$ & $0 \%$ & $8 \%$ \\
\hline \multirow[t]{4}{*}{ Endosulfan I } & $\overline{\mathrm{x}} \pm \mathrm{SD}$ & $0.30 \pm 0.86$ & $0.05 \pm 0.36$ & $0.31 \pm 0.86$ & $0.01 \pm 0.04$ \\
\hline & $\mathrm{Me}$ & 0.00 & 0.00 & 0.00 & 0.00 \\
\hline & $\left(\mathrm{x}_{\min }-\mathrm{x}_{\max }\right)$ & $(1.71-3.85)$ & $(2.49-2.49)$ & $(0.02-4.06)$ & $(0.10-0.23)$ \\
\hline & > LOD $\%$ & $13 \%$ & $2 \%$ & $50 \%$ & $21 \%$ \\
\hline \multirow[t]{4}{*}{ pp'DDE } & $\overline{\mathrm{x}} \pm \mathrm{SD}$ & $0.10 \pm 0.08$ & $0.03 \pm 0.04$ & $0.20 \pm 0.27$ & $0.05 \pm 0.08$ \\
\hline & $\mathrm{Me}$ & 0.10 & 0.00 & 0.02 & 0.00 \\
\hline & $\left(\mathrm{x}_{\min }-\mathrm{x}_{\max }\right)$ & $(0.05-0.31)$ & $(0.04-0.15)$ & $(0.03-0.88)$ & $(0.02-0.34)$ \\
\hline & > LOD\% & $71 \%$ & $73 \%$ & $75 \%$ & $73 \%$ \\
\hline \multirow[t]{4}{*}{ Dieldrin } & $\overline{\mathrm{x}} \pm \mathrm{SD}$ & $3.81 \pm 3.14$ & $0.51 \pm 1.21$ & $2.18 \pm 2.33$ & $0.27 \pm 0.40$ \\
\hline & $\mathrm{Me}$ & 4.30 & 0.00 & 0.98 & 0.00 \\
\hline & $\left(\mathrm{x}_{\min }-\mathrm{x}_{\max }\right)$ & $(0.19-9.01)$ & $(0.13-4.80)$ & (1.09-6.34) & $(0.03-1.44)$ \\
\hline & > LOD $\%$ & $75 \%$ & $75 \%$ & $83 \%$ & $71 \%$ \\
\hline
\end{tabular}


Table 1 (continued)

\begin{tabular}{|c|c|c|c|c|c|}
\hline Pesticide & & Raw water, $n=144$ & Drinking water, $n=144$ & Raw sewage, $n=144$ & Treated sewage, $n=144$ \\
\hline \multirow[t]{4}{*}{ Endrin } & $\overline{\mathrm{x}} \pm \mathrm{SD}$ & $0.02 \pm 0.08$ & $0.00 \pm 0.00$ & $0.21 \pm 0.80$ & $0.09 \pm 0.50$ \\
\hline & $\mathrm{Me}$ & 0.00 & 0.00 & 0.00 & 0.00 \\
\hline & $\left(\mathrm{x}_{\min }-\mathrm{x}_{\max }\right)$ & $(0.41-0.42)$ & $(0.00-0.00)$ & $(0.32-3.39)$ & $(0.08-3.32)$ \\
\hline & $>\mathrm{LOD} \%$ & $4 \%$ & $0 \%$ & $23 \%$ & $8 \%$ \\
\hline \multirow[t]{4}{*}{ Endosulfan II } & $\bar{x} \pm S D$ & $0.40 \pm 0.44$ & $0.09 \pm 0.16$ & $1.00 \pm 1.41$ & $0.14 \pm 0.25$ \\
\hline & $\mathrm{Me}$ & 0.41 & 0.00 & 0.14 & 0.00 \\
\hline & $\left(\mathrm{x}_{\min }-\mathrm{x}_{\max }\right)$ & $(0.31-1.94)$ & $(0.15-0.85)$ & $(0.15-4.73)$ & $(0.19-1.03)$ \\
\hline & $>\mathrm{LOD} \%$ & $58 \%$ & $63 \%$ & $79 \%$ & $67 \%$ \\
\hline \multirow[t]{4}{*}{ pp'DDD } & $\overline{\mathrm{x}} \pm \mathrm{SD}$ & $0.47 \pm 1.30$ & $0.02 \pm 0.04$ & $0.60 \pm 1.53$ & $0.07 \pm 0.17$ \\
\hline & $\mathrm{Me}$ & 0.06 & 0.00 & 0.06 & 0.00 \\
\hline & $\left(\mathrm{x}_{\min }-\mathrm{x}_{\max }\right)$ & $(0.03-5.70)$ & $(0.02-0.23)$ & $(0.01-7.01)$ & $(0.02-0.94)$ \\
\hline & $>$ LOD $\%$ & $75 \%$ & $75 \%$ & $92 \%$ & $83 \%$ \\
\hline \multirow[t]{4}{*}{ Endrin aldehyde } & $\overline{\mathrm{x}} \pm \mathrm{SD}$ & $0.01 \pm 0.03$ & $0.00 \pm 0.01$ & $0.03 \pm 0.06$ & $0.01 \pm 0.03$ \\
\hline & $\mathrm{Me}$ & 0.00 & 0.00 & 0.00 & 0.00 \\
\hline & $\left(\mathrm{x}_{\min }-\mathrm{x}_{\max }\right)$ & $(0.16-0.18)$ & $(0.04-0.06)$ & $(0.08-0.22)$ & $(0.06-0.17)$ \\
\hline & > LOD\% & $4 \%$ & $4 \%$ & $38 \%$ & $21 \%$ \\
\hline \multirow[t]{4}{*}{ Endosulfan sulfate } & $\overline{\mathrm{x}} \pm \mathrm{SD}$ & $0.01 \pm 0.03$ & $0.00 \pm 0.00$ & $0.02 \pm 0.08$ & $0.00 \pm 0.02$ \\
\hline & $\mathrm{Me}$ & 0.00 & 0.00 & 0.00 & 0.00 \\
\hline & $\left(\mathrm{x}_{\min }-\mathrm{x}_{\max }\right)$ & $(0.14-0.15)$ & $(0.00-0.00)$ & $(0.17-0.35)$ & $(0.09-0.12)$ \\
\hline & $>\mathrm{LOD} \%$ & $4 \%$ & $0 \%$ & $17 \%$ & $4 \%$ \\
\hline \multirow[t]{4}{*}{$\mathrm{pp}^{\prime} \mathrm{DDT}$} & $\bar{x} \pm S D$ & $0.15 \pm 0.14$ & $0.06 \pm 0.16$ & $0.11 \pm 0.13$ & $0.05 \pm 0.07$ \\
\hline & $\mathrm{Me}$ & 0.14 & 0.00 & 0.03 & 0.00 \\
\hline & $\left(\mathrm{x}_{\min }-\mathrm{x}_{\max }\right)$ & $(0.07-0.59)$ & $(0.04-1.10)$ & $(0.05-0.45)$ & $(0.04-0.28)$ \\
\hline & $>$ LOD $\%$ & $75 \%$ & $69 \%$ & $83 \%$ & $79 \%$ \\
\hline \multirow[t]{4}{*}{ Endrin ketone } & $\overline{\mathrm{x}} \pm \mathrm{SD}$ & $0.21 \pm 0.23$ & $0.05 \pm 0.10$ & $0.30 \pm 0.46$ & $0.08 \pm 0.11$ \\
\hline & $\mathrm{Me}$ & 0.18 & 0.00 & 0.00 & 0.00 \\
\hline & $\left(\mathrm{x}_{\min }-\mathrm{x}_{\max }\right)$ & $(0.13-1.00)$ & $(0.02-0.40)$ & $(0.27-1.53)$ & $(0.12-0.32)$ \\
\hline & $>\mathrm{LOD} \%$ & $63 \%$ & $63 \%$ & $67 \%$ & $63 \%$ \\
\hline \multirow[t]{4}{*}{ Methoxychlor } & $\overline{\mathrm{x}} \pm \mathrm{SD}$ & $0.12 \pm 0.25$ & $0.03 \pm 0.05$ & $0.18 \pm 0.26$ & $0.03 \pm 0.04$ \\
\hline & $\mathrm{Me}$ & 0.07 & 0.00 & 0.01 & 0.00 \\
\hline & $\left(\mathrm{x}_{\min }-\mathrm{x}_{\max }\right)$ & $(0.05-1.31)$ & $(0.03-0.16)$ & $(0.06-0.91)$ & $(0.04-0.14)$ \\
\hline & $>\mathrm{LOD} \%$ & $58 \%$ & $63 \%$ & $75 \%$ & $71 \%$ \\
\hline \multirow{5}{*}{$\begin{array}{l}\Sigma \text { Organochlorine pes- } \\
\text { ticides }\end{array}$} & $\overline{\mathrm{x}} \pm \mathrm{SD}$ & $19.13 \pm$ & $2.73 \pm 4.01$ & $14.82 \pm$ & $3.37 \pm 4.62$ \\
\hline & $\mathrm{Me}$ & 12.41 & 0.12 & 15.25 & 0.47 \\
\hline & $\left(\mathrm{x}_{\min }-\mathrm{x}_{\max }\right)$ & 23.38 & $(0.07-12.21)$ & 7.82 & $(0.02-14.97)$ \\
\hline & $>\mathrm{LOD} \%$ & $(0.15-36.55)$ & $68 \%$ & $(0.07-41.26)$ & \\
\hline & & $100 \%$ & & $73 \%$ & $68 \%$ \\
\hline
\end{tabular}

Notes: the table reports summary statistics expressed as ng/l. For each organochlorine pesticides, we report the mean $(\bar{x}) \pm s t a n d a r d$ deviation (SD), median (Me), range (in bracket), and detection frequency (\%)

decreased or were eliminated completely (with decreases of 46 to $100 \%$ ), which demonstrates the effectiveness of the water treatment methods applied (Table 1). The health risk associated with the ingestion of drinking water was assessed based on the calculated LADD and HQ values (Figs. 4 and 5). The results for LADD (from $2.27 \cdot 10^{-9}$ to $4.07 \cdot 10^{-7} \mathrm{mg}$ / $\mathrm{kg} /$ day) point to very low levels of organochlorine 
Fig. 4 The lifetime average daily dose (LADD) for the removal of organochlorine pesticide residues for adults after ingestion of raw water and drinking water, a statistically significant value $(p<0.05)$, b statisti$(p<0.05)$ cally insignificant value

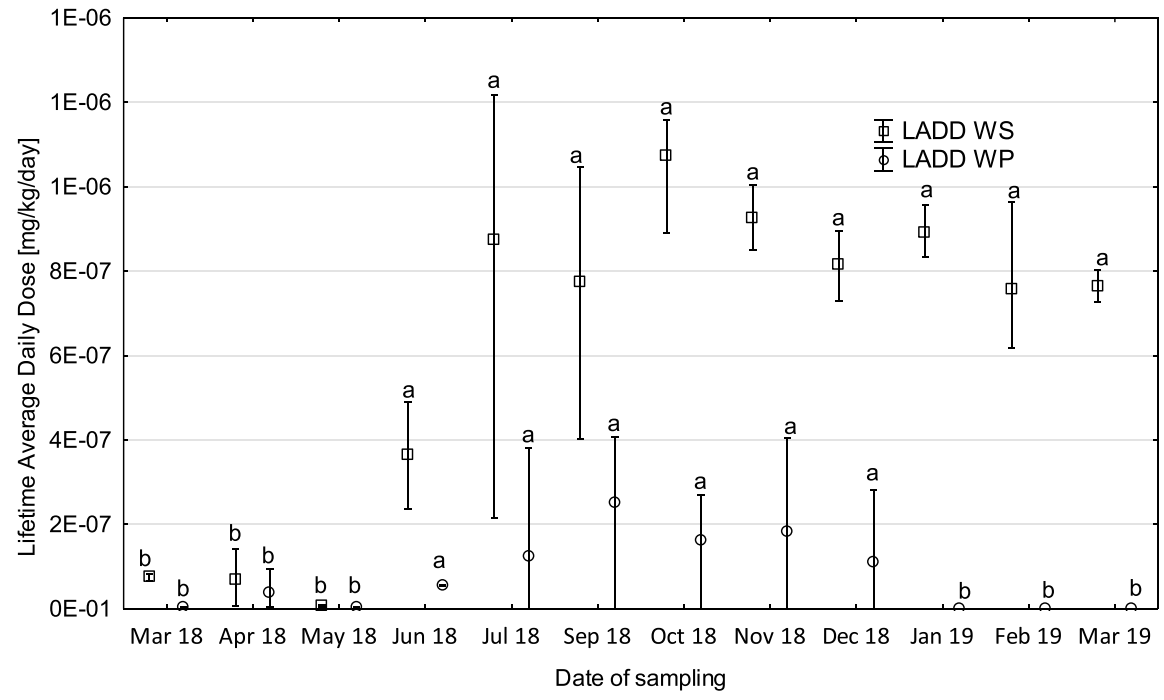

Fig. 5 Hazard quotient (HQ) for organochlorine pesticide residues after ingestion of raw water and drinking water for an adult, a statistically significant value $(p<0.05)$, b statistically insignificant value $(p<0.05)$

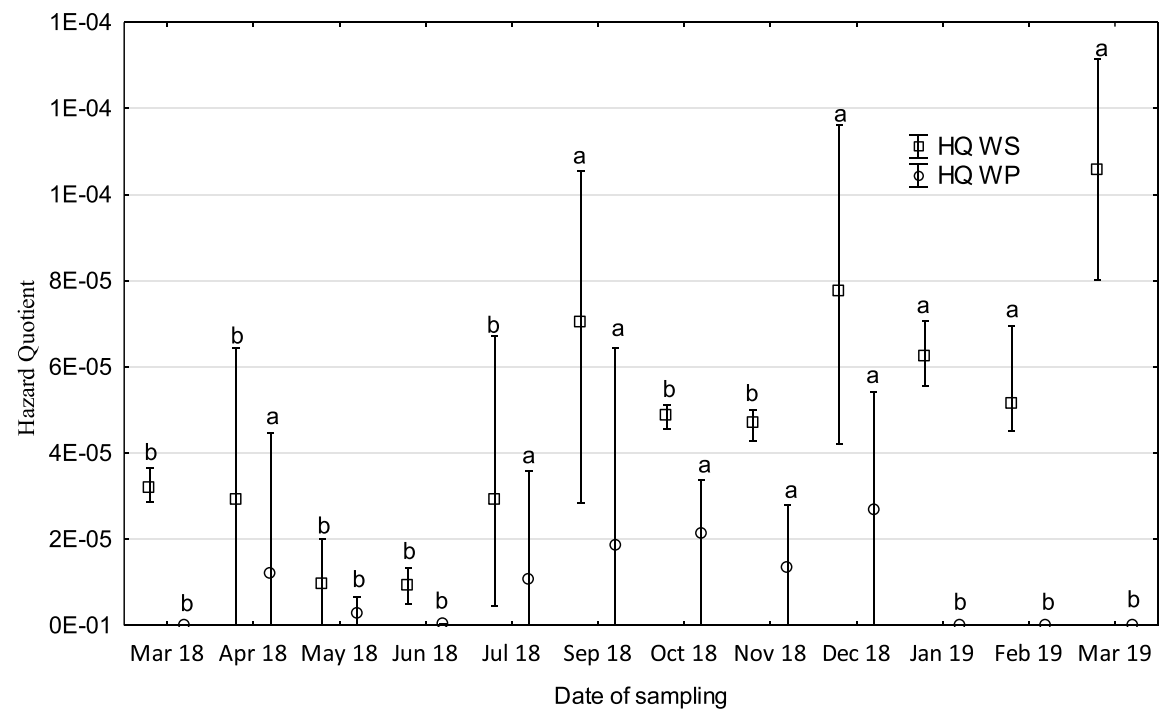

pesticide intake from drinking water. The HQ levels for drinking water ranged from $3.42 \cdot 10^{-9}$ to $6.44 \cdot 10^{-5}$ and thus were well below the limit of 1 . This indicates that the water is safe for consumers to drink and does not pose a health hazard.

\subsection{Untreated Sewage}

$\mathrm{HCH}$ compounds (>LOD) were found to be present in an average of $84.4 \%$ of the untreated sewage samples $(\alpha \mathrm{HCH}, 83 \% ; \beta \mathrm{HCH}, 92 \%$; $\gamma \mathrm{HCH}, 79 \% ; \delta \mathrm{HCH}$, $83 \%$ ). The highest average content of the sum of $\mathrm{HCHs}$ in untreated sewage $(17.06 \mathrm{ng} / \mathrm{L})$ was detected in November, with the annual average being $7.2 \mathrm{ng} / \mathrm{L}$. DDT metabolites (>LOD) were found to be present in an average of $83 \%$ of the untreated sewage samples (pp'DDE, 75\%; pp'DDD, 92\%; pp'DDT, 83\%). The lowest average content of the sum of DDT and their metabolites was found in untreated sewage in June $(3.31 \mathrm{ng} / \mathrm{L})$, with the annual average being $0.91 \mathrm{ng} / \mathrm{L}$. Of these, the metabolite pp'DDD was the predominant compound. The average fraction of $\mathrm{pp}^{\prime} \mathrm{DDT}$ in the sum of DDT was 0.25 , indicating that no new quantities of the compound were introduced.

Endosulfan species ( $>$ LOD) were found to be present in an average of $48 \%$ of the untreated sewage 
samples (endosulfan I, 50\%; endosulfan II, 79\%; endosulfan sulfate, 17\%). The highest content of the sum of endosulfan compounds was found in November $(3.27 \mathrm{ng} / \mathrm{L})$, with the average for the study period being $1.34 \mathrm{ng} / \mathrm{L}$. As was the case in the water samples, endosulfan II showed the highest levels, proving to be the major metabolite.

The content of the sums of organochlorine pesticides in untreated sewage was significantly higher $(p<0.05)$ from May to November 2018 relative to the other periods.

\subsection{Treated Sewage}

$\mathrm{HCH}$ compounds (>LOD) were found to be present in an average of $79 \%$ of the treated sewage samples $(\alpha \mathrm{HCH}, 79 \% ; \beta \mathrm{HCH}, 96 \%$; $\mathrm{\gamma HCH}, 71 \% ; \delta \mathrm{HCH}$, $71 \%$ ). The highest average content of the sum of $\mathrm{HCHs}$ in treated sewage $(6.3 \mathrm{ng} / \mathrm{L})$ was detected in June, with the average for the study period at $1.94 \mathrm{ng} / \mathrm{L}$. Of these, the ${ }^{\mathrm{HCH}} \mathrm{H}$ isomer was the predominant compound.

DDT metabolites (>LOD) were found to be present in an average of $78.5 \%$ of the treated sewage samples (pp'DDE, 73\%; pp'DDD, 83\%; pp'DDT, $79 \%$ ). The lowest average content of the sum of DDT and their metabolites in untreated sewage was also found in June $(0.91 \mathrm{ng} / \mathrm{L})$, the average level being $0.16 \mathrm{ng} / \mathrm{L}$. Of these, the metabolite pp'DDD was the major compound. The average fraction of $\mathrm{pp}^{\prime} \mathrm{DDT}$ in the sum of DDT was 0.21 , indicating that no new quantities of the compound were introduced.
Endosulfan species (>LOD) were found to be present in an average of $30 \%$ of the treated sewage samples (endosulfan I, 21\%; endosulfan II, 67\%; endosulfan sulfate, $4 \%$ ), with the average being $0.16 \mathrm{ng} / \mathrm{L}$. The highest content of the sum of endosulfan species was found in November $(0.68 \mathrm{ng} / \mathrm{L})$, with endosulfan II being the most common species of its type.

Maximum admissible concentrations of organochlorine pesticides are set out in the Regulation (Dz. U., item 1311, 2019) on parameters of treated sewage discharge into water. The detected trace amounts of organochlorine pesticides such as $\mathrm{HCH}$, aldrin, DDT, and HCB (ranging from $0.01 \cdot 10^{-6}$ to $4.9 \cdot 10^{-6} \mathrm{mg} / \mathrm{L}$ ) were close to the $0 \mathrm{mg} / \mathrm{L}$ level defined as the maximum admissible concentration in the Regulation. The results show that the treated sewage discharged into the Odra river was not hazardous to the aquatic environment (Fig. 6).

The content of the sums of organochlorine pesticides in treated sewage was significantly higher $(p<0.05)$ in June and July 2018 relative to the other periods.

Additionally, when the levels of analytes of interest were compared between untreated and treated sewage via a Tukey's test $(p<0.05)$, the results showed that pesticide residues in treated sewage significantly decreased or were eliminated completely (with decreases of $37 \%$ to $100 \%$ ), which demonstrates the effectiveness of the water treatment methods applied (Table 1).
Fig. 6 Sum of organochlorine pesticides in annual terms in raw sewage and treated sewage, a statistically significant value $(p<0.05)$, b statistically insignificant value $(p<0.05)$

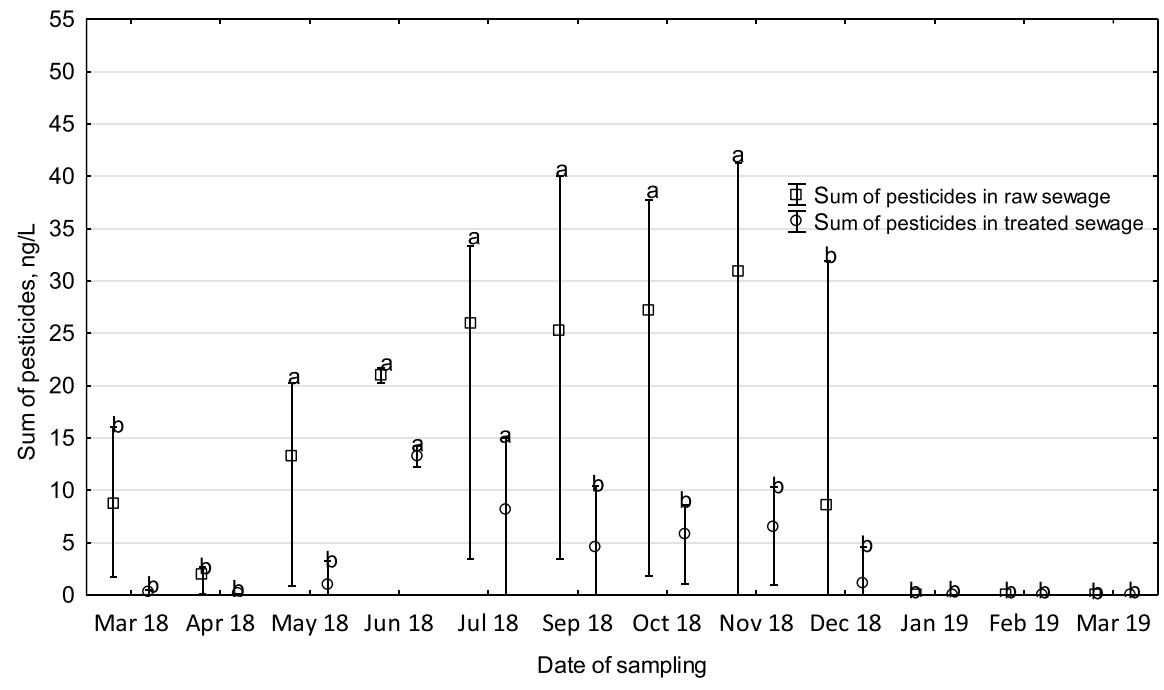




\section{Discussion}

Research across the world shows that causes of insecticides infiltrating water bodies may include reckless and irresponsible use of organochlorine pesticides, incorrect storage, careless disposal of containers, and application of obsolete products, which have been the main contributors to water pollution in Ethiopia and Pakistan (Essumang et al., 2009, Hashim, 2015, Mekonen et al., 2016). Among the many classes of insecticides, organochlorine pesticides are considered to be the most dangerous. This group includes aldrin, dieldrin, chlordane, DDT, DDA, DDD, endrin, heptachlor, mirex, toxaphene, and HCH. Their 95\% decomposition rate can range from 1 to 30 years (Grotowska et al., 2018). Sums of HCH (5.54-13.08 ng/L) and DDT (0.17-4.47 ng/L) were found in drinking water in China, though at levels deemed safe (Wei et al., 2015, Lehmann et al., 2017).

Even many years after these compounds ceased to be produced, they clearly continue to persist in the environment and pose a real hazard across the world. Despite the limitations on the use of organochlorine pesticides (OCPs) now in place, DDT is still used in China to manufacture dicofol, resulting in these compounds being continuously released into the environment. However, Shao et al., (2016) showed that the sums of DDT in surface waters of Beijing had dropped significantly from 91.8 (2002) to $0.257 \mathrm{ng} / \mathrm{L}$ (2015-2016). The literature data indicates that $\mathrm{HCH}$ and DDT isomers continue to be found in drinking water sources worldwide. The highest concentrations of sums of DDT and $\mathrm{HCH}$ are found in Africa $(\Sigma \mathrm{HCH}$ 6-234 ng/L and $\Sigma$ DDT 8-239 ng/L) and Asia ( $\Sigma \mathrm{HCH}$ 76-100 ng/L and $\Sigma$ DDT 116-848 ng/L) (El Bouraie et al., 2011, Kaushik et al., 2012). An assay of water sampled from Wrocław intakes by Pawełczyk (2013) found the presence of OCP residues at a level of $73.53 \mathrm{ng} / \mathrm{L}$. Tests of tap water, conducted by the Poviat Unit of the State Sanitary Inspection in Szczecin from 2014 to 2017, showed that the levels of OCPs, which were initially at MRL values, dropped to residues at and around the LOQ (Raport RSSE Szczecin 2017). The water testing results obtained in this study - an examination that included tap water in Szczecin - showed low values of OCP residues that did not exceed the MRL.

The catchment areas of Lake Miedwie are used for agriculture. The results show that the water has been contaminated with trace amounts of the compounds, possibly owing to the agricultural activity during the last several decades. However, there may also be other sources of pollution, such as atmospheric pollution from the energy/transport industries and the often unreported discharges of untreated domestic sewage from nearby villages. In summary, it should be emphasized that when compared with other countries, the treat water from Lake Miedwie does not contain levels of OCPs pesticide residues dangerous to Szczecin inhabitants. The levels of these compounds are well within maximum admissible concentrations, with the average level corresponding to $0.55 \%$ MRL. The drinking water supplied to the citizens of Szczecin conformed with all standards. Its chemical and microbiological purity is being continuously monitored, with such exemplary parameters as turbidity of $0.1-0.2$ NTU (nephelometric turbidity unit); $\mathrm{pH}$ (potential of hydrogen) of 7.4-7.8; alkalinity of $3 \mathrm{mmol} / \mathrm{L}$; chlorine dioxide at $0.3-0.4 \mathrm{mg}$; COD (chemical oxygen demand) at $2.4-3 \mathrm{mg} / \mathrm{L}$; nitrates at $1.55-3.65 \mathrm{mg} / \mathrm{L}$; and nitrites maximally at $0.001 \mathrm{mg} / \mathrm{L}$. This indicates that the quality of the water is comparable to commercial bottled water products.

The analysis also showed that despite the modern methods used both in the water treatment plant and in the sewage treatment plant, $100 \%$ removal was not achieved. An analysis of the results revealed that, during the study period, the water treatment process lowered the organochlorine pesticide concentration by approximately $80 \%$ (45-100\%). The sewage treatment process showed higher efficiency at around $85 \%$ (37-100\%). The organochlorine compounds analyzed in the present study are currently not used in the European Union. Their considerable persistence in the environment (up to 30 years) and their ability to accumulate in tissues mean that they are still detected in the environment.

The aim of the study was to comprehensively evaluate the effectiveness of the raw water treatment process used in ZPW in Żelewo in terms of reducing OCP residues in drinking water. The facility uses conventional, proven treatment methods. As indicated by Syafrudin et al. (2021), an alternative to such solutions may be purification processes based on the in situ generation of a highly reactive hydroxyl radical that oxidizes resistant organic pollutants. In this process, organic pollutants are fully mineralized to 
carbon dioxide, water, minerals, and salt. Hydroxyl radicals can be produced in various ways, e.g., using a combination of oxidants, catalysts, and ultraviolet radiation (Syafrudin et al., 2021).

Preventing area-wide surface water pollution is a complex issue that has yet to be solved. It is not always possible to locate the site of discharge or to determine the type of pollutant. When substances are transported from the catchment area to water bodies due to snowmelt or rainfall, the physiography and use of the catchment and water regimes are of primary importance. When aiming to reduce area-wide pollution, consideration must be given to the nature of the catchment area, the hydrological cycle, and the reactions to changing weather conditions. Water pollution can cause economic losses and lead directly to potential food contamination (Ciećko \& Panek, 2019).

\section{Conclusions}

1. OCP residues in the drinking water average $0.55 \%$ MRL (ranging from 0.01 to $2.44 \%$ MRL) and present no direct risk to the health of consumers and are safe to consume.

2. The levels of OCPs in treated sewage were low (from 0.02 to $14.97 \mathrm{ng} / \mathrm{L}$ ) relative to applicable standards.

3. The water treatment process successfully lowered the OCP concentration by approximately $80 \%$ (from 46 to $100 \%$ ).

4. The sewage treatment process successfully lowered the OCP concentration by approximately $85 \%$ (from 37 to $100 \%$ ).

Open Access This article is licensed under a Creative Commons Attribution 4.0 International License, which permits use, sharing, adaptation, distribution and reproduction in any medium or format, as long as you give appropriate credit to the original author(s) and the source, provide a link to the Creative Commons licence, and indicate if changes were made. The images or other third party material in this article are included in the article's Creative Commons licence, unless indicated otherwise in a credit line to the material. If material is not included in the article's Creative Commons licence and your intended use is not permitted by statutory regulation or exceeds the permitted use, you will need to obtain permission directly from the copyright holder. To view a copy of this licence, visit http://creativecommons.org/licenses/by/4.0/.

\section{References}

Aryal, J., Gautam, B., \& Sapkota, N. (2012). Drinking water quality assessment. Journal of Nepal Health Research Council, 10(22), 192-196.

Ciećko, P., Panek, P. (2019). Water contamination in PolandThe status of surface and underground inland water bodies. Monographs of the Environmental Engineering Committee. Publisher of the Polish Academy of Sciences, 58-80.

Cosgrove, W. J., \& Loucks, D. P. (2015). Water management: Current and future challenges and research directions. Water Resources Research, 51, 4823-4839.

Directive, 1998 Council directive 98/83/EC of 3 November 1998 on the quality of water intended for human consumption. https://eur-lex.europa.eu/legal-content/EN/TXT/HTML/? uri=CELEX:31998L0083\&from $=$ PL

Dz. U., item 2294 (Journal of laws), 2017. Regulation of the Minister of Health of 7 December 2017 on the quality of water intended for human consumption. http://prawo.sejm. gov.pl/isap.nsf/DocDetails.xsp?id=WDU20170002294

Dz. U., item 1311 (Journal of laws), 2019. Regulation Minister for Maritime Economy and Inland Navigation of July 12,2019 on substances that are particularly harmful to the aquatic environment and the conditions to be met when entering wastewater or into the ground, as well as when discharging rainwater or snowmelt to waters or water facilities. http://isap.sejm.gov.pl/isap.nsf/download.xsp/ WDU20190001311/O/D20191311.pdf

El Bouraie, M., El Barbary, A., \& Yehia, M. (2011). Monitoring of chlorinated hydrocarbon compounds residues in surface water and bed sediment samples from El-Rahawy drai Egypt. International Journal of Environmental Sciences, 1, 1931-1947.

Essumang, D. K., Togoh, G. K., \& Chokky, L. (2009). Pesticide residues in the water and fish (lagoon tilapia) samples from lagoons in Ghana. Bulletin of the Chemical Society of Ethiopia, 23, 19-27.

EU Commission Directive. 2002/63/EC of 11 July 2002 Establishing Community Methods of Sampling for the Official Control of Pesticide Residues in and on Products of Plant and Animal Origin and Repealing Directive 79/700/EEC (2002). https://eur-lex.europa.eu/legal-content/EN/TXT/ $\mathrm{PDF} /$ ?uri=CELEX:32002L0063\&from $=\mathrm{EN}$. (accessed on July 18, 2020).

Farhaoui, M., \& Derraz, M. (2016). Review on optimization of drinking water treatment process. Journal of Water Resource and Protection, 8, 777-786.

Feng, L., Yang, G., Zhu, L., Xu, J., Xu, X., \& Chen, Y. (2016). Distribution and risk assessment of endocrine-disrupting pesticides in drinking water sources from agricultural watershed. Water Air and Soil Pollution, 227, 23.

Grotowska, M., Janda, K., \& Jakubczyk, K. (2018). Effect of pesticides on human health. Pomeranian Journal of Life Sciences, 64, 42-50.

Hashim, M. (2015). Pesticides and drinking water. Journal of Advanced Botany and Zoology, 3(1), ISSN: 2348-7313, $1-5$.

Kaushik, C. P., Sharma, H. R., \& Kaushik, A. (2012). Organochlorine pesticide residues in drinking water in the rural 
areas of Haryana, India. Environmental Monitoring and Assessment, 184, 103-112.

Koniuch, A., \& Małozięć, D. (2007). Rules of conduct when carrying out rescue operations with plant protection products. Part I - Plant protection products-Introduction. Safety and Fire Technique, 1, 217-234.

Lana, R., Vavrova, M., Caslavsky, J., Skoumalova, M., Bilkova, A., \& Sucman, E. (2008). PCBs in samples from the environment of the southern Moravia region Czech Republic. Bulletin of Environmental Contamination and Toxicology, 81, 574-577.

Lehmann, E., Turrero, N., Kolia, M., Konaté, Y., \& Alencasto, L. (2017). Dietary risk assessment of pesticides from vegetables and drinking water in gardening areas in Burkina Faso. Science of the Total Environment, 601-602, 1208-1216.

Li, Y. Q., Wu, Y. L., Chen, Y. G., \& Kong, Z. M. (2006). Genotoxicity evaluation and a primary risk assessment of organic pollutants in the drinking water sources of Nanjing. Journal of Environmental Sciences, 18, 983-988.

Mekonen, S., Argaw, R., Simanesew, A., Houbraken, M., Senaeve, D., Ambelu, A., \& Spanoghe, P. (2016). Pesticide residues in drinking water and associated risk to consumers in Ethiopia. Chemosphere, 162, 252-260.

Olutona, G. O., Ayano, S. A., \& Obayomi-Davies, O. (2014). Organochlorine pesticide in water and bottom sediment from Aiba Reservoir (Southwestern Nigeria). Chemistry and Ecology, 30(6), 513-531.

Pawełczyk, A. (2013). Assessment of health risk associated with persistent organic pollutants in water. Environmental Monitoring and Assessment, 185, 497-508.

Pawełczyk, A. (2013). Assessment of health risk associated with persistent organic pollutants in water. Environmental Monitoring and Assessment, 185, 497-508.

Perelló, G., Gómez-Catalán, J., Castell, V., Llobet, J. M., \& Domingo, J. L. (2012). Assessment of the temporal trend of the dietary exposure to PCDD/Fs and PCBs in Catalonia, over Spain: Health risks. Food and Chemical Toxicology, 50, 399-408.
Piccoli, C., Cremonese, C., Koifman, R. J., Koifman, R., \& Freire, C. (2016). Pesticide exposure and thyroid function in an agricultural population in Brazil. Environmental Research, 151, 389-398.

Polanco Rodríguez, A. G., Riba López, M. I., Del Valls Casillas, T. A., Araujo León, J. A., Mahjoub, O., \& Prusty, A. K. (2017). Monitoring of organochlorine pesticides in blood from of women with uterine cervix cancer. Environmental Pollution Part B, 220, 853-862.

Syafrudin, M., Kristanti, R. A., Yuniarto, A., Hadibarata, T., Rhee, J., Al-onazi, W. A., Algarni, T. S., Almarri, A. H., \& Al-Mohaimeed, A. M. (2021). Pesticides in drinking water-A review. International Journal of Environmental Research and Public Health, 18, 468. https://doi.org/10. 3390/ijerph18020468

Shao, Y., Han, S., Ouyang, J., Yang, G., Liu, W., Ma, L., Luo, M., \& Xu, D. (2016). Organochlorine pesticides and polychlorinated biphenyls in surface water around Beijing. Environmental Science Pollution Research, 23, 24824-24833.

Tsindos, S. (2012). What drove us to drink 2 litres of water a day? Australian and New Zealand Journal of Public Health, 36(3), 205-207.

Wee, S. Y., \& Aris, A. Z. (2017). Endocrine disrupting compounds in drinking water supply system and human health risk implication. Environment International, 106, 207-233.

Wei, G. L., Li, D., Zhuo, M., Liao, Y., Xie, Z., Guo, T., Li, J., Zhang, S., \& Liang, Z. (2015). Organophosphorus flame retardants and plasticizers: Sources, occurrence, toxicity and human exposure. Environmental Pollution, 196, 29-46.

Publisher's Note Springer Nature remains neutral with regard to jurisdictional claims in published maps and institutional affiliations. 